ISSN 1014-4874

DOI : http://dx.doi.org/10.4314/rj.v26i1.1

\title{
A Spatial Analysis of Poverty in Kigali, Rwanda using indicators of household living standard
}

\author{
${ }^{1}$ Felicia O. Akinyemi and ${ }^{2}$ Florent Bigirimana \\ ${ }^{1}$ Department of Estate Management and Valuation \\ Kigali Institute of Science and Technology \\ B.P. 3900 Avenue de l'Armee, Kigali, RWANDA \\ felicia.akinyemi@gmail.com \\ ${ }^{2}$ National Institute of Statistics of Rwanda \\ MIS unit/GIS Section
}

\begin{abstract}
This study examines the poverty pattern occurring in Kigali through the use of spatial analysis techniques. It seeks to further decipher the underlying factors contributing to the emerging pattern of poverty. These kinds of information are useful to the Kigali administration as input into devising appropriate poverty reduction strategy for the city. Household living standard is examined using data from the Integrated Living Condition survey (EICV: Enquête Intégrale sur les Conditions de vie des ménages) conducted by the National Institute of Statistics of Rwanda in 2000-2001. It was meant to measure household expenditures, consumption and income, as well as demographic and socioeconomic characteristics of the population. Four poverty dimensions were employed in the analysis of urban poverty in Kigali, namely: expenditure, health, education, and services. The influence exerted by each dimension on the overall poverty level is examined. Several indices were computed such as the poverty headcount, poverty gap and a composite household living standard index. Looking at the example of the poverty headcount index, three distinct regions of poverty incident can be deciphered. In the first region with the highest poverty incident, the number of poor is between 32-78\%. These are the extreme southern and north-western part of Kigali comprising of south Kicukiro, south Gikondo and south Butamwa districts and the north-western part of Gisozi District. The second region of medium poverty incident has between 12-32\% of its population poor. These are the north of Gisozi, eastern part of Kanombe, northern portions of Kicukiro, Gikondo and Butamwa districts. The third region of low poverty incident has between $4-12 \%$ of its population poor. This region consists mainly of Kacyiru, Kanombe, Nyarugenge, the northern parts of Nyamirambo and Gikondo districts, and the south of Gisozi district. The poverty pattern shows a clear urban and rural dichotomy.
\end{abstract}

Key words: Spatial analysis, Geographic Information System (GIS), Poverty, Household living standard, EICV, Kigali 


\section{Introduction}

Poverty is the major problem facing a lot of people in the $21^{\text {st }}$ century. The Millennium Development Goals (MDGs) comprising of 8 goals and 21 targets to be achieved by the year 2015 are adopted by different countries (UNDP 2006). Of these targets, that on reducing extreme poverty is the first one. At the national level, Rwanda undertakes diverse plans and programmes to achieve the MDGs. In Rwanda, development priorities are based on numerous strategies such as the Vision 2020, the EDPRS (Economic Development and Poverty Reduction Strategies). The Vision 2020 is a long term development road map for 20 years that started in year 2000 with the objectives of raising the Rwandan population out of poverty and transforming the country into a middle-income, knowledge based economy (Ministry of Finance and Economic Planning - MINECOFIN 2000). The EDPRS is a second medium term strategy ${ }^{1}$ toward attainment of this long term vision 2020 objectives (see MINECOFIN 2007, 2009). However good a policy is, it is not sufficient on its own to eradicate poverty. Policy implementation is an important issue to be considered. This makes it imperative to assess policy implementation over time in order to see how policy objectives are being achieved.

The National Institute of Statistics Rwanda (NISR) is mandated by the government to track and monitor issues relating to economic development and poverty reduction performance indicators. This it does by producing and managing all statistics relevant in this regard. One such survey is the Integrated Living Condition survey (EICV: Enquête Intégrale sur les Condiltions de vie des ménages). To date, two EICVs have been conducted in Rwanda. The first survey (EICV1) was conducted in 2000-2001 to measure household expenditures, consumption and income, as well as demographic and socioeconomic characteristics of the population. The second survey (EICV2) conducted 2005-2006 is primarily intended to capture changes in consumption and poverty levels on a national basis.

This study analyses urban poverty in Kigali based on data from the first EICV. The second survey data was found unusable in this study because the spatial sampling frame is unavailable. Four poverty dimensions were employed in the analysis of urban poverty in Kigali, namely: expenditure, health, education, and services. The goal is to determine who is poor (according to the poverty line ${ }^{2}$ ), how many poor people are there (referred

\footnotetext{
${ }^{1}$ The first was Poverty Reduction Strategy Paper

${ }^{2}$ The value of income or expenditure per person that is needed to consume food and other items for a healthy living is defined as the poverty line (PL). Households
} 
to as headcount ${ }^{3}$ ), and how poor are the poor (poverty gap ${ }^{4}$ ). The term poverty is used in this paper in a broad sense to include poverty and other related themes. Poverty is associated with insufficient income or consumption as well as insufficient outcomes with respect to health, nutrition and literacy. So it is interesting to assess poverty by combining monetary poverty measurement and non-monetary poverty measurement.

A GIS based analysis of poverty is important as poverty levels have a space and a time component. It allows the display and spatial analysis of poverty which aids the understanding of the causes of poverty. This can be achieved using a multicriteria analysis that combines a variety of information such as natural resources, topography, infrastructures, amongst others. Combining poverty indicators with geo-referenced datasets such as soil fertility, slope, land use, water access points, etc. helps to highlight areas where, for example, poverty overlaps with other socio-economic and environmental challenges (Bedi et al. 2007). Cartographic representations of welfare indicators ranging from nutritional status to educational level can be used in combination with geospatial information on environmental conditions to design programmes that address problems across a range of geographic scale, (Davis 2003). GIS as a tool plays a key role for decision makers in order to target poverty reduction programmes.

This study has as its objectives the following:

- poverty analysis based on household living conditions in Kigali city

- develop a GIS based procedure for assessing household living standards

- quantify the contribution each indicator/dimension makes to the poverty level

A GIS based analysis requires that the original survey data be georeferenced, else it cannot be analysed and the results mapped. Georeferencing implies that there is a linkage between the survey data and the geographic location to which the data pertains. It is not general practice in Rwanda to have survey data geo-referenced. In the case of the EICVs, the

that cannot meet their basic needs such as nutrition, health, and education are said to be below the PL. The PL varies from country to country and for a country at different times.

${ }^{3}$ Headcount ratio is the proportion of a population that is deemed to be poor, whose income or consumption level falls below the poverty line.

${ }^{4}$ The poverty gap indicates how far poor people are below the poverty line. It measures the amount of money to be transferred annually to the poor to lift them out of poverty. 
data have been collected and analyzed separately from their spatial sampling frame. Consequently, there is a lack of a powerful spatial analysis component. Even if results of a survey can be disaggregated to the administrative units, heterogeneity within the same administrative unit can be great. This necessitated the conduct of this research given that it has never been done before in Rwanda. The development of a GIS based procedure for assessing household living standards is useful for giving future guidance on analysing demographic and socio-economic datasets as the procedure can also be replicated elsewhere in Rwanda.

The paper outline is as follows: an introduction is given detailing poverty reduction strategies in Rwanda. A background to measuring poverty is also given. This is followed by an overview of poverty analysis and a description of the the GIS based procedure developed and utilized in the study. The paper presents the results of the poverty analysis conducted in Kigali city. Lastly, the amount of influence exerted by the household living condition dimensions on the overall poverty levels is examined.

\section{Background to measuring poverty}

In measuring poverty, three steps to be taking are: 1) defining an indicator of welfare; 2) establishing a minimum acceptable standard of that indicator; and 3) generating a summary statistics to aggregate the information from the distribution of each welfare indicator relative to the poverty line.

In defining a welfare indicator, the common approach is to measure economic welfare based on household consumption expenditure or income. When divided by the household size, this gives a per capita measure of consumption expenditure or income. Of course, there are also nonmonetary measures of individual welfare, which can include indicators such as infant mortality rates in the region, life expectancy, proportion of spending devoted to food, housing conditions, and child schooling. Wellbeing is a broader concept than economic welfare, which only measures a person's command over commodities. The establishment of a minimum acceptable standard of each indicator helps to separate the poor from the non-poor. It is deemed necessary to achieve an adequate standard of living in a given country. Most commonly used is the cost of basic needs approach. It first estimates the cost of acquiring enough food for adequate nutrition - usually 2,100 Calories per person per day - and then adds on the cost of other essentials such as clothing and shelter (World Bank 2009, p. 42).

For the last step on generating summary statistics to aggregate all indicators relative to the poverty line, several indices are used. The most popularly 
used is the econometric measure referred to as the Foster-Greer-Thorbecke class of decomposable poverty indices (FGT indices) which addresses poverty in its three dimensions of poverty incidence, intensity and severity among a given population. This is the basis for calculating the poverty headcount, poverty gap and poverty severity (Squared Poverty Gap Index SPGI) indices (see Foster et al. 1984). The headcount index measures the proportion of the population that is poor. It is popular because it is easy to understand and measure. But it does not indicate how poor the poor are. The poverty gap index measures the extent to which individuals fall below the poverty line (the poverty gaps) as a proportion of the poverty line. However, the measure does not reflect changes in inequality among the poor. The SPGI or $\mathrm{P}^{2}$ is the measure for severity of poverty by means of the inequality among poor. The FGT index has been used in several studies to generate overall poverty indices at national, sub-national, and/or socioeconomic levels of interest (see Kanbur 1987, Baker and Grosh 1994, Osberg and Kuan 2008).

For the non-monetary measures of poverty, the Human Poverty Index developed by the United Nations Development Program (UNDP) is commonly used. The HPI is a composite index of deprivations of basic human capabilities in three fundamental dimensions. These are a long and healthy life, as measured by the percentage of people not expected to survive to the age of 40 years; knowledge as measured by adult illiteracy rate. Lastly, is deprivation in economic provisioning, from private and public income, as measured by Gross National Product per capita. Furthermore, the percentage of people lacking access to health services, safe water and the like can be integrated to reflect local conditions (UNDP 2000, 2005).

Urban poverty presents a set of issues distinct from general poverty analysis and thus may require additional tools and techniques. While the dimensions of poverty are many, there is a subset of characteristics that are more pronounced for the poor in urban areas and may require specific analysis: examples are commoditization (reliance on the cash economy), overcrowded living conditions (slums), environmental hazard (stemming from density and hazardous location of settlements, and exposure to multiple pollutants), social fragmentation (lack of community and interhousehold mechanisms for social security, relative to those in rural areas), crime and violence, traffic accidents and natural disasters. A minimum set of indicators that may be useful as basic instruments for capturing urban poverty is suggested in Table 1. 


\section{Study area}

The study area, Kigali city, is lying approximately between latitude $1^{0} 50^{1} \mathrm{~S}$ $-2^{0} 50^{1} \mathrm{~S}$ and longitude $29^{0} 50^{1} \mathrm{E}-30^{0} 15^{1} \mathrm{E}$ (Figure 1). The city comprises of 8 districts, namely: Gisozi, Butamwa, Kicukiro, Nyarugenge, Kacyiru, Nyamiranbo, Gikondo and Kanombe. It is a fact that the current administrative boundaries already changed from that of 2002. Using the current administrative divisions for the data analysis will be meaningless as a survey data is only meaningful for the spatial frame (locality) with which it was collected. Since the first EICV survey data of 2000-2001 will be incompatible with the new administrative divisions, Kigali city is considered with its boundaries of 2002. However, in the construction of the maps of the poverty results, the current administrative boundaries are used. This is to make the results to be better understood and useful for policy within the context of the present administrative units. EICV survey has a sample of 900 households, grouped into 100 clusters as enumeration areas (Zone de Dénombrement - ZD), at a rate of 9 household per cluster. Clusters are spatially distributed as shown in Figure 1.

Table 1: Indicators of Urban Poverty

\begin{tabular}{|c|c|c|}
\hline $\begin{array}{l}\text { Poverty } \\
\text { dimensions }\end{array}$ & Intermediate indicators & $\begin{array}{l}\text { Impact/outcome } \\
\text { indicators }\end{array}$ \\
\hline Income & $\begin{array}{l}\text { Access to credit (e.g. percentage of } \\
\text { the target population using or eligible } \\
\text { for credits from formal finance } \\
\text { organizations, for housing and } \\
\text { productive uses) or the share of } \\
\text { credits used by the target group in the } \\
\text { total loans offered by formal finance } \\
\text { organizations) } \\
\text { Shares of informal employment } \\
\text { Household expenditures on housing } \\
\text { (lowest two quintiles) } \\
\text { Model shares of transport for work } \\
\text { trips } \\
\text { Household expenditures on transport } \\
\text { (lowest two quintiles) } \\
\text { Mean travel time to work, Coverage } \\
\text { of social assistance } \\
\text { Access to electricity } \\
\text { Regulatory delays (such as licensing } \\
\text { burdens on SMEs) } \\
\text { Land development controls }\end{array}$ & $\begin{array}{l}\text { Poverty headcount } \\
\text { Poverty gap } \\
\text { Extreme poverty } \\
\text { incidence } \\
\text { Female-headed } \\
\text { households in poverty } \\
\text { Income inequality } \\
\text { (Gini coefficient) } \\
\text { Quintile ratio of } \\
\text { inequality } \\
\text { Unemployment rate } \\
\text { Housing price/income } \\
\text { ratio }\end{array}$ \\
\hline Health & Household expenditures on potable & Maternal mortality rate \\
\hline
\end{tabular}




\begin{tabular}{|c|c|c|}
\hline & $\begin{array}{l}\text { water and sanitation } \\
\text { Percentage of households connected } \\
\text { to water/sewerage } \\
\text { Per capita consumption of water } \\
\text { Percentage of wastewater treated } \\
\text { Percentage of households with regular } \\
\text { solid waste collection } \\
\text { Percentage of solid waste safely } \\
\text { disposed of } \\
\text { Crowding (housing floor space per } \\
\text { person) } \\
\text { Air-pollution concentrations } \\
\text { Shares of sources of household energy } \\
\text { Access to primary health services } \\
\text { Access to nutritional safety net } \\
\text { Household expenditures on health } \\
\text { care (lowest two quintiles) } \\
\text { Household expenditures on food } \\
\text { (lowest two quintiles) }\end{array}$ & $\begin{array}{l}\text { Life expectancy at } \\
\text { birth } \\
\text { Female-male gap in } \\
\text { health (under-5 } \\
\text { mortality rate by sex) } \\
\text { Malnutrition rate of } \\
\text { children } \\
\text { Morbidity and } \\
\text { mortality rates from } \\
\text { public } \\
\text { health/environment- } \\
\text { related diseases (e.g. } \\
\text { diarrheal, respiratory, } \\
\text { malaria) } \\
\text { Death rates by } \\
\text { violence } \\
\text { Injury/death rates by } \\
\text { transport accidents } \\
\text { Mortality rates by } \\
\text { disaster }\end{array}$ \\
\hline Education & $\begin{array}{l}\text { Primary and secondary school } \\
\text { enrollment rates } \\
\text { Access to vocational training } \\
\text { Share of household expenditures on } \\
\text { education (lowest two quintiles) }\end{array}$ & $\begin{array}{l}\text { Literacy rate } \\
\text { School completion } \\
\text { rates } \\
\text { Gender gap in } \\
\text { education attainment, } \\
\text { Child labour } \\
\text { Street children }\end{array}$ \\
\hline $\begin{array}{l}\text { Security } \\
\text { Tenure } \\
\text { Personal }\end{array}$ & $\begin{array}{l}\text { Population in unauthorized housing } \\
\text { Population living in precarious zones } \\
\text { Scope of disaster } \\
\text { prevention/mitigation measures } \\
\text { Access to police and legal system } \\
\text { protections }\end{array}$ & $\begin{array}{l}\% \text { of households with } \\
\text { secure tenure, Deaths } \\
\text { from industrial or } \\
\text { environmental disasters } \\
\text { Murder rates (rates of } \\
\text { other crimes, e.g child } \\
\text { abuse,. domestic } \\
\text { violence, robbery) }\end{array}$ \\
\hline Empowerment & $\begin{array}{l}\text { Extent of public consultation in local } \\
\text { government budget decisions } \\
\text { Participation of residents in political } \\
\text { or community organizations } \\
\text { Discrimination in access to } \\
\text { services/jobs } \\
\text { Access to telephones and internet }\end{array}$ & $\begin{array}{l}\text { Citizen involvement } \\
\text { and access to } \\
\text { information in local } \\
\text { government decisions } \\
\text { Satisfaction with city } \\
\text { services }\end{array}$ \\
\hline
\end{tabular}

Source: Baharoglu and Kessides 2002, p. 132 


\section{Methodology}

\subsection{Data used}

Two kinds of data have been used for this research, namely spatial data and attribute data. The spatial datasets comprise of the map of the ZDs and administrative boundaries of districts and sectors (these datasets were created by the cartography section of the then National Census Service, now NISR).

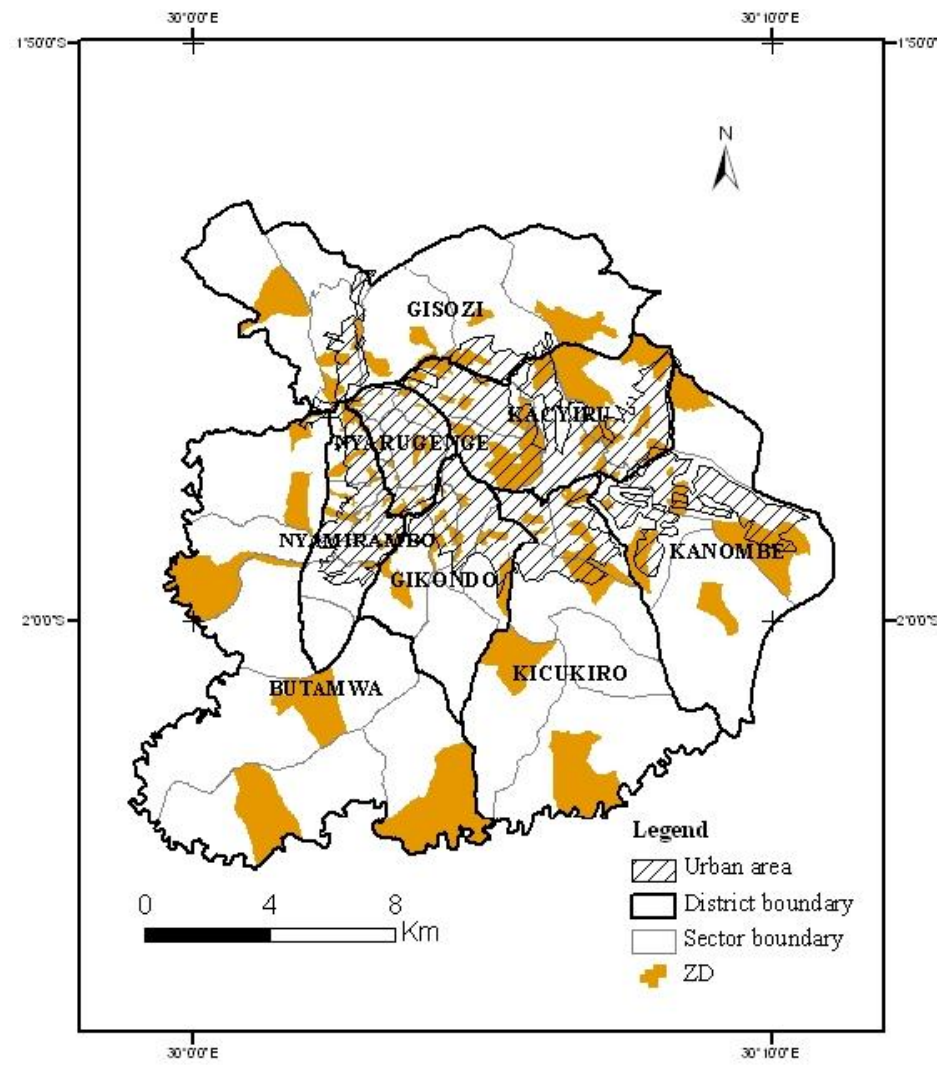

Figure 1: Location map of Kigali city comprising of urban and rural areas as of 2005

The attribute datasets are derived from the EICVs survey. This survey captured information on household income production, consumption and expenditure including the demographic, social and economic characteristic of the population such as employment, health and level of education. A database with household living standard indicators was compiled. In this study, four dimensions of household living conditions were utilized in computing urban poverty in Kigali city. These are expenditure/income, 
health, education and access to services. Each dimension is captured through some indicators as described in Table 2.

Table 2: Household living condition indicators utilised in the study

\begin{tabular}{|c|c|c|}
\hline No. & Dimensions & Description of indicators \\
\hline \multirow[t]{2}{*}{1} & \multirow[t]{2}{*}{ Expenditure/income } & Poverty headcount \\
\hline & & Poverty gap ratio \\
\hline 2 & Health & $\begin{array}{l}\text { Percentage of people using medical health } \\
\text { care Percentage of people without any } \\
\text { medical insurance }\end{array}$ \\
\hline \multirow[t]{3}{*}{3} & \multirow[t]{3}{*}{ Access to services } & Percentage of people using safe water \\
\hline & & $\begin{array}{l}\text { Percentage of households without a water } \\
\text { closet or chemical toilet }\end{array}$ \\
\hline & & $\begin{array}{l}\text { Housing: Percentage of population in sub- } \\
\text { standard housing }\end{array}$ \\
\hline \multirow[t]{2}{*}{4} & \multirow[t]{2}{*}{ Education } & $\begin{array}{l}\text { Enrolment rate at primary and secondary } \\
\text { level of education }\end{array}$ \\
\hline & & $\begin{array}{l}\text { Illiteracy rate: Percentage of persons age } \\
15+\text { with no schooling }\end{array}$ \\
\hline
\end{tabular}

\subsection{Poverty analysis}

For the four dimensions, ten indicators of household living conditions have been compiled at the cluster level to calculate different poverty indices. In Rwanda, the moderate poverty line is 64,000 Frw per adult per year whereas for extreme poverty it is 45,000 Frw per adult was used in January 2001 prices. Converting these poverty lines into January 2006 prices, gives values of 90,000 Frw per adult per year for the moderate poverty line and $63,500 \mathrm{Frw}$ for the extreme poverty line. This translates to a poverty line of 250 Frw per day per adult and 175 Frw for the extreme poverty line (see NISR, 2006, p. 3).

The poverty headcount index helps us to know households below the poverty line. It was calculated from the consumption per household data derived from the EICV survey as follows:

$$
P h i=\frac{N i}{P i} \times 100
$$

Where:

Phi is the Poverty Headcount in cluster i 
$\mathrm{Ni}$ is the number of households whose consumption is below the poverty line in cluster $\mathrm{i}$

$P i$ is the total number of household in cluster $\mathrm{i}$

The poverty gap index expresses the inequality among the poor as the sum of the population below the poverty line, divided by the total population. This is calculated as follows:

$$
P G=\frac{1}{n} \sum_{i-l}^{q}\left[\frac{Z-Y i}{Z}\right]
$$

Where:

$z$ is the poverty line

$y_{i}$ is the income of individual i

$q$ is the number of poor people

$n$ is the size of the population

This formula is applicable based on data on individuals ( $y_{i}$ as individual income or consumption). If household-level data are used, the formula have to be adjusted by the weight $w_{i}$, which is the household size multiplied by the sampling expansion factor for every household $i$ (World Bank 2009, p. 70).

\subsection{Spatial analysis}

Various activities were carried out under spatial analysis (see Figure 2). Figure 2 shows the model describing the steps taken in conducting spatial analysis within the study. The Figure summarizes the procedure employed to run the whole process of the spatial analysis. 


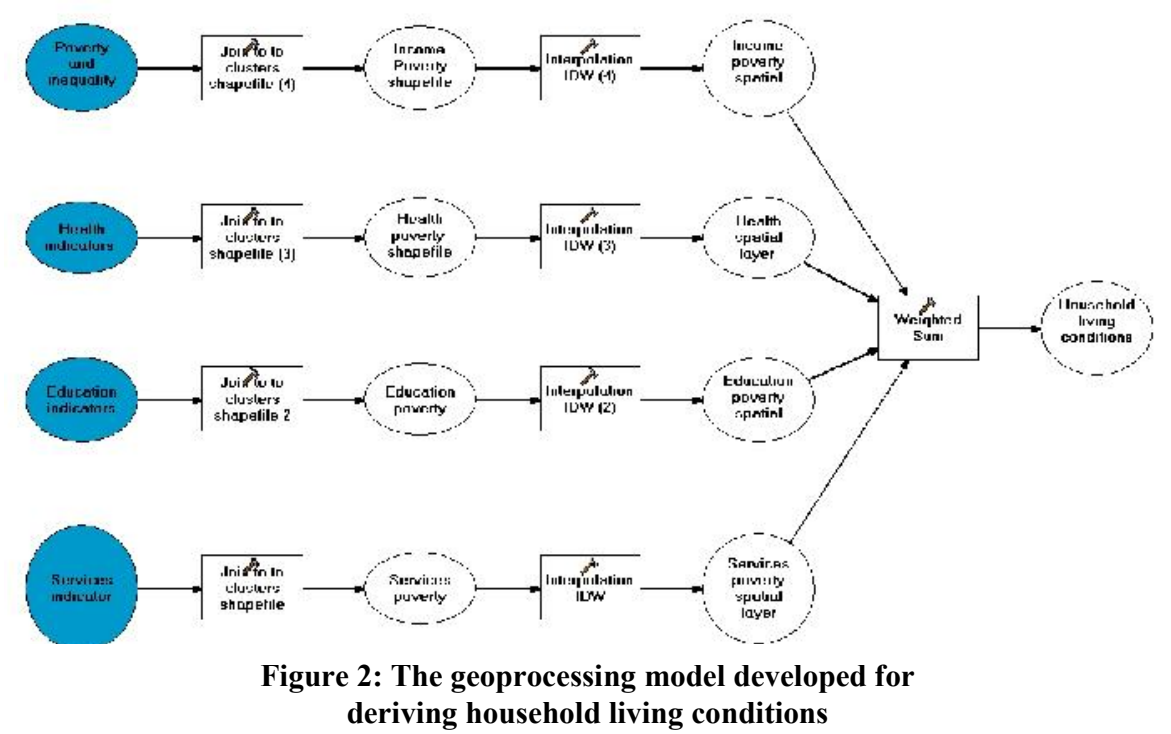

The model has 3 elements: inputs (coloured ellipse), process (rectangle with a tool icon) and the outputs (plain ellipse). Inputs are the spatial sampling frame used in the EICV survey and their attribute datasets. The process is a GIS function used for spatial analysis. Three functions have been used: Joining tables, interpolation and weighted sum overlay. The outputs are results of the processes. As evident in Figure 2, there are intermediate and final outputs. Intermediate outputs are results from the interpolation process, whereas the final output is the integrated household living condition layer.

The initial step in the procedure is to combine indicators within each poverty dimension based on the EICV data. Most crucial information needed for the analysis is the geographic location to which the datasets pertain. The demographic and socio-economic data are then linked to the spatial data of the ZDs which are represented in the GIS as centroid points. This process of joining helps to integrate tables of indicators to their survey sampling frame. The next step is to apply an interpolation function to create the continuous raster surface of each poverty dimension. The layers so created are then combined by an overlay function to generate an integrated household living standard index.

Spatial interpolation is a technique used to estimate a value of a variable at an unsampled location from measurements made at other sites. There are many methods for interpolation such as 1) Thiesen polygons (Thiessen 1911); 2) Splining (Fleming et al. 2000, Jeffrey et al. 2001); 3) Kriging 
(Hudson and Wachkernagel 1994); 4) Inverse Distance Weighting (IDW) (Hartkamp et al. 1999); 5) Gradient plus inverse-distance-squared (Price et al. 2000); and 6) Neural networks (Antonic et al. 2001, Rigol et al. 2001). Thiessen polygon for example, was not used because it produces sharp boundaries, whereas others have less parameters to enable one control the model better. Only Kriging, IDW and Radial basis function (RBF) have been used but none of these three methods is the best for all datasets (i.e. there is no one solution fits all method). The choice of one to another depends first on the results produced as well as on cross validation assessment. The cross validation assessment is a process of comparing the results from diverse interpolation methods in order to choose the best using some statistical parameters like the root mean square error, mean error, regression model, etc. For the overlay, the weighted sum overlay tool was used which provides the ability to weight and combine multiple inputs to create an integrated analysis. It works by multiplying the designated field values for each input raster by the specified weight. It then sums (adds) all input rasters together to create one output raster (see Figure 3).

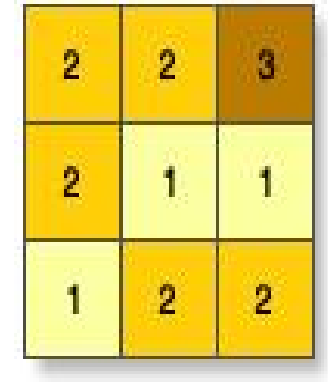

InRas1

(influence $75 \%)$

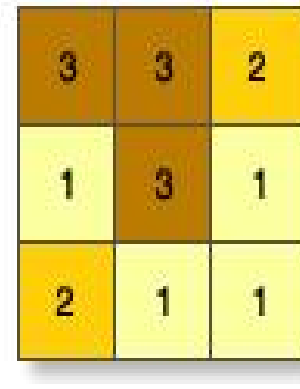

InRas 1

(influence

$25 \%)$

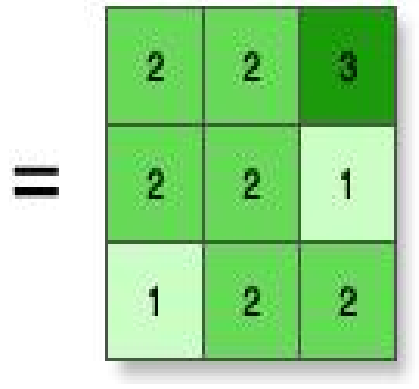

OutRas

Figure 3: Illustrating how the weighted sum overlay works (Source: ESRI 2010)

In the illustration, the two input rasters have been reclassified to a common measurement scale of 1 to 3 . Each raster is assigned a percentage influence. The cell values are multiplied by their percentage influence and the results are added together to create the output raster. For example, considering the top left cell, the values for the two inputs become $(2 * 0.75)=1.5$ and $(3 * 0.25)=0.75$. The sum of 1.5 and 0.75 is 2.25 . Because the output raster from Weighted Overlay is integer, the final value is rounded to 2 
(ESRI, 2010). Since there is no one common indicator for welfare in this study, to perform an evaluation of household living standards, we had to combine the ten indicator layers earlier explained in Table 2.

\section{Results}

\subsection{Poverty incidence}

The incidence of poverty is obtained by considering the poor as those whose expenditures are below the poverty line $(90,000 \mathrm{Frw})$. Figure 4 shows the map of the distribution of the poor in Kigali city. Results in Figure 4 reveal the patterns of poverty in Kigali city. Majority of the poor, between $32-78 \%$ of the population are to be found in the south and northwest region. These are locations south of Kicukiro, Gikondo and Butamwa

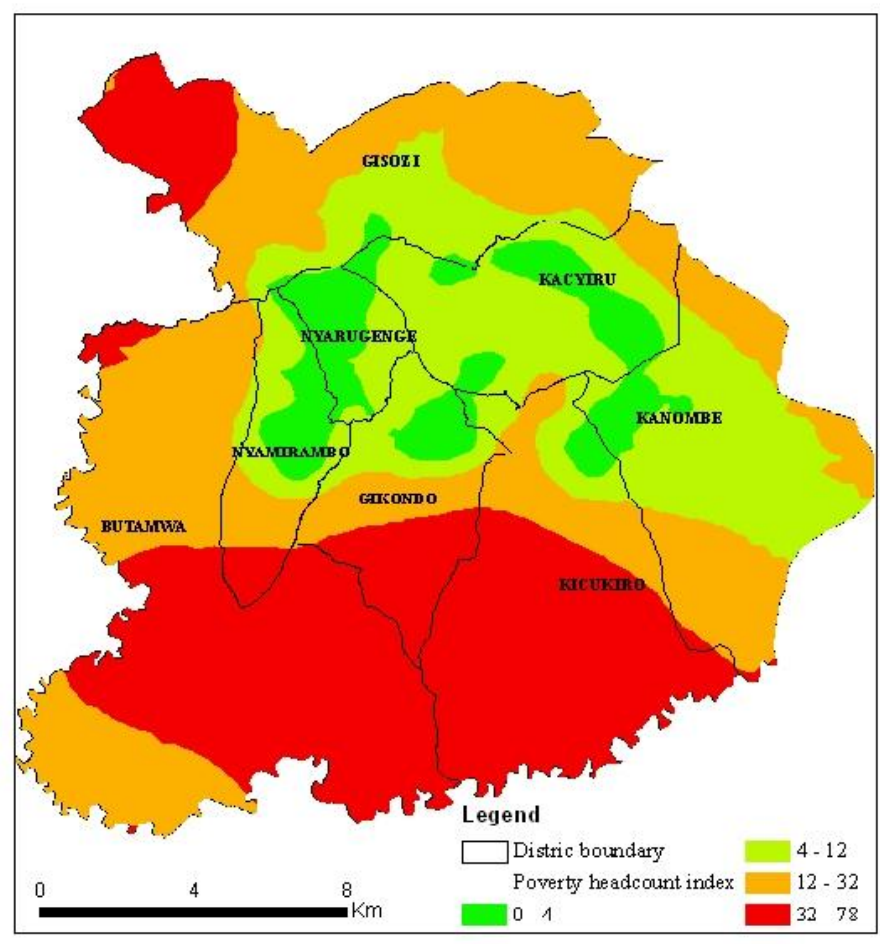

Figure 4: Poverty headcount index in Kigali city districts and the north-west of Gisozi district. The next poverty pattern is that with medium poverty incidence, between $12-32 \%$.

These are locations in the north of Gisozi, southern and eastern part of Kanombe, northern portions of Kicukiro, Butamwa and central Gikondo districts. The areas of low poverty incidence have between $0-4 \%$ and $4-12 \%$ of its population poor. There are locations in Kacyiru, Kanombe, Nyarugenge, the northern parts of Nyamirambo and Gikondo districts, and the south of Gisozi district. The poverty pattern shows a clear urban and rural dichotomy because this region of low poverty incidence is mainly urban. 


\subsection{Poverty gap (intensity)}

The Figure 5 shows the distribution of inequality among the poor in Kigali. The illustrates how intense poverty is in Kigali, that is, how far below the poverty line the poor are to be found. Poverty is most intense in the western and eastern parts of the City in Butamwa (north and central), Kanombe and Kicukiro (south). Poverty intensity is lowest mostly in scattered portions of Gikondo, Nyarugenge, Kacyiru and Kicukiro whereas poverty intensity is medium in the central, north and south-west parts of Kigali City.

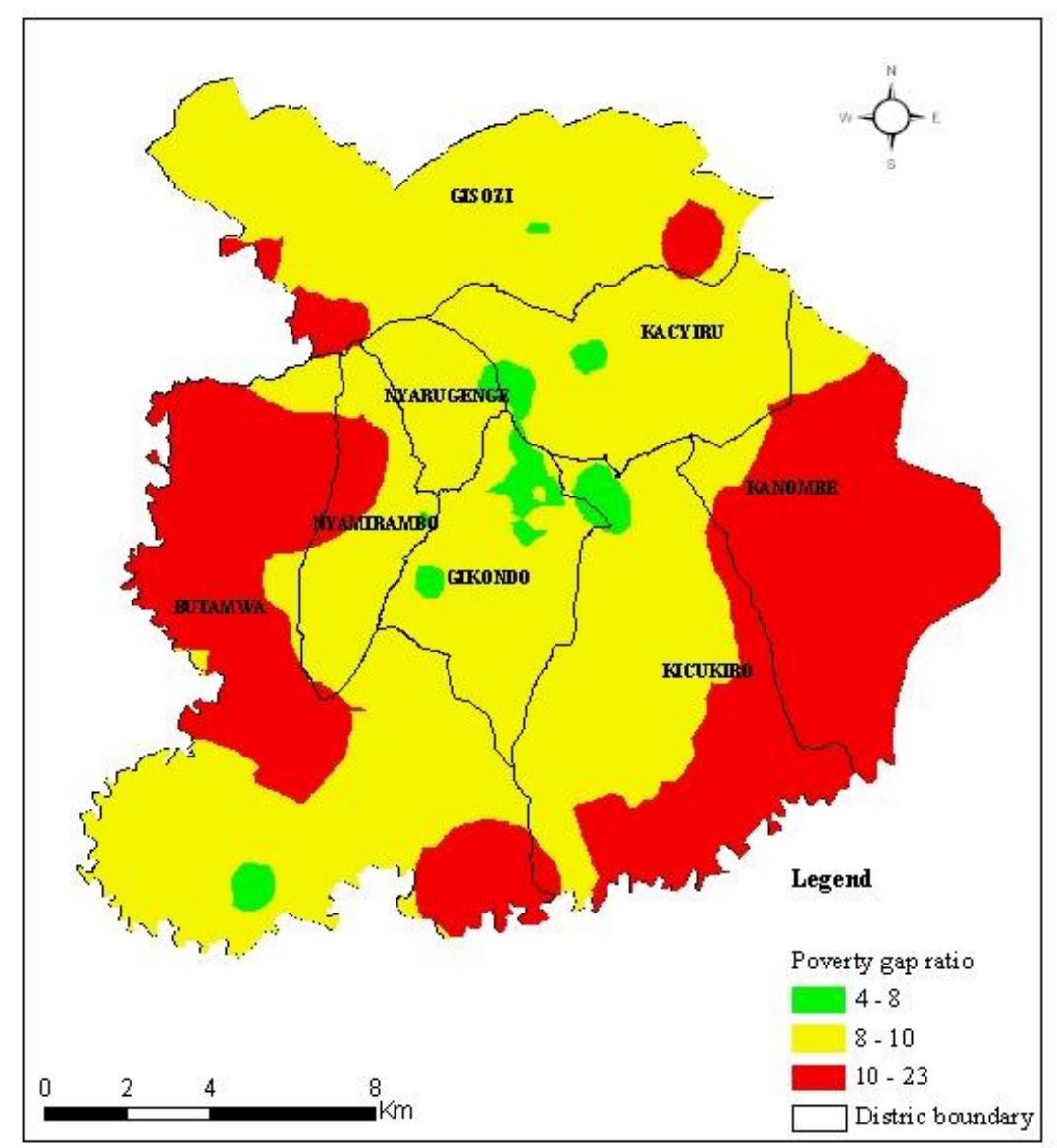

Figure 5: Poverty gap in Kigali city 


\subsection{Composite household living conditions}

Using the GIS based procedure as described in sub-section 3.3, an assessment of household living conditions in Kigali city was made. Household living conditions are determined by the sum of certain number of welfare indicators. These indicators can be monetary such as income or expenditure or non-monetary such as education, health, accessibility to public services, etc. For each indicator chosen in this study, a corresponding spatial layer has been created. These layers were combined to generate a composite index of household living condition. The variation in household living condition is better interpreted when equated to the poverty level. Where the household living condition is low, then poverty is high and vice versa. The result is a spatial layer showing variations in the distribution of poverty levels in Kigali city (see Figure 6).

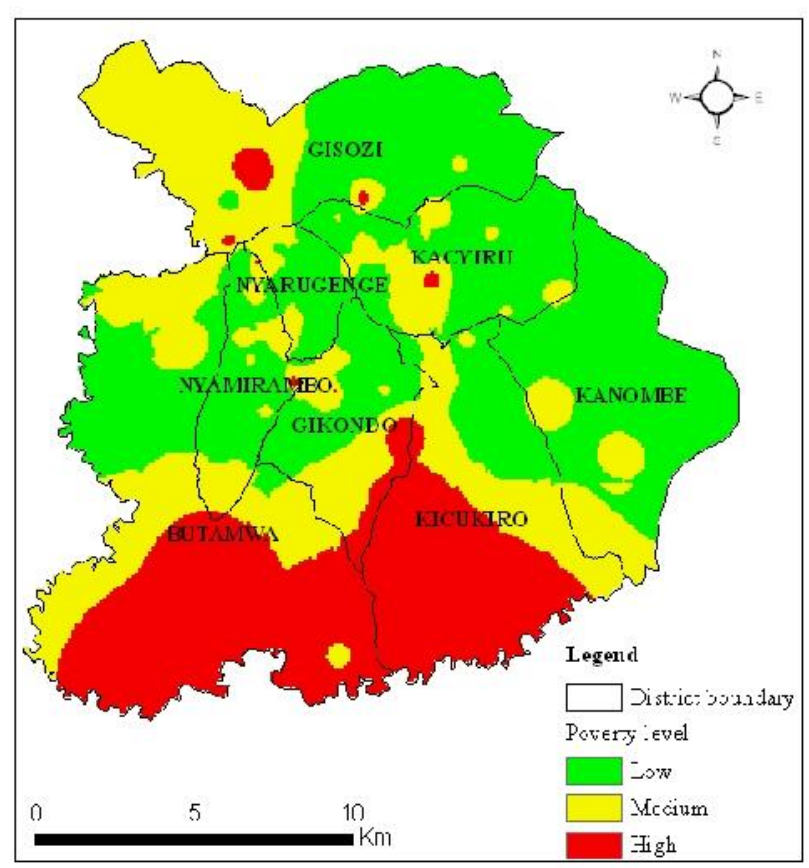

Figure 6: Distribution of poverty levels in Kigali city

A common scale from 0 to 100 was used for the cells values for combining the layers of indicators. Since these cell values also connote percentages, this composite layer of household living condition was reclassified into three categories of poverty for ease of interpretation. These are high poverty level equates to low household living standard (53-69\%), medium poverty level equates to medium household living standard $(47-52 \%)$ and low poverty level equates to high household living standard $(22-46 \%)$.

\section{Discussion}

This discussion focuses on deciphering the key patterns of household living standards in Kigali city. It most be noted that the delimitation of the 
administrative boundaries of the city of Kigali at various times never took into account the reality of urbanized and rural areas. The current boundary includes a considerably large rural area which cannot be at the same level of development as the urban areas. A little bit of history of Kigali city shows that until 1962, its urban development was minimal and limited primarily to the Nyarugenge hill. The city plans of 1948 and 1958 show that the only two areas of Kigali that were developed were the historic core on top of the Nyarugenge hill and the core of the muslim area in Nyamirambo (south of the Nyarugenge). In 1964, a conceptual master plan for Kigali was established delimiting areas around Nyarugenge hill for extension of the city to locate affordable housing. As at 1975, the growth of Kigali has exceeded the area delimited in 1964. In the early 1980's, another plan was developed delimiting new areas for residential expansion primarily in Nyamirambo, Gikondo, Kicukiro, Remera, Kimihurura and Kacyiru as well as develop an industrial area near the airport. In 1984, the urban population of Kigali was approximately 160,000 people and the urban area occupied around 15 sq. kilometers. The population and the extent of the built up area expanded until the 1994 genocide. Since 1999, the urban population of Kigali has grown at a rate of about $8 \%$ annually. Currently, the density of the Kigali urban area is about 86 persons per hectare. Much of this development has occurred in marginal areas such as wetlands and areas of steep slopes. According to the Kigali City Council (2007), 19\% of the built environment of Kigali is on land that is not suitable for development.

Looking closely at all the spatial layers of household living standard indicators created, a contrast is evident between the south, the central and the north-west part of Kigali city. The central part of the city shows better living conditions whatever the indices chosen, whereas other parts vary from medium to low living conditions. This central part, that is, the districts of Nyarugenge, Nyamirambo, Kacyiru, Gikondo and Kanombe are areas of early urbanization. The south, especially the district of Butamwa and the south of Kicukiro district are completely rural areas which have never been urbanized. They were included in the city with the legislation of 2001 which extended the Kigali city to these rural areas. The same can be said of the north-west part of Gisozi District. In these parts, household living conditions appear to be better than elsewhere in Kigali city. However, there are some pockets of high poverty as in the southern part of the city. This can be explained as being a consequence of rural-urban migration of people moving from rural area expecting better things offered by the city. On arrival, they cannot afford these things and end up concentrating in slums where living conditions in households are deteriorating. 
Based on Figure 6, the city is zoned into 3 according to the poverty level (zone where poverty level is low, zone where poverty level is medium and the zone where poverty level is high). The contributions of the different dimensions of household living standards to the perceived pattern were identified to better understand which of these dimensions have more impact than others. This is useful to the authorities in order to better know how to react and prioritize action. An average index was computed for every indicator in each of the three zones and table 3 shows the weight of each dimension.

Table 3: Household living standard dimensions' (weight in percentages)

\begin{tabular}{|l|c|c|c|c|c|}
\hline Poverty level & $\begin{array}{l}\text { Expenditure } \\
\text { Income }\end{array}$ & Health & Education & Services & \\
\hline Low & 2 & 27 & 27 & 45 & 100 \\
\hline Medium & 3 & 25 & 27 & 45 & 100 \\
\hline High & 6 & 25 & 26 & 43 & 100 \\
\hline Total score/percentage & $11 / 3.66$ & $77 / 25.58$ & $80 / 26.58$ & $133 / 44.19$ & \\
\hline
\end{tabular}

The table implies that in the zone where poverty level is low, the expenditure/income dimension contributed only $2 \%$, health and education contributed $27 \%$ respectively and services contributed $45 \%$ to the overall poverty level. This is further illustrated in Figure 7 which shows the influence that every dimension brings into the overall poverty level. The Figure shows that access to services by households have a greater influence on overall poverty pattern in Kigali city, irrespective of the zone whether low or high poverty level. This finding is very interesting from the policy point of view in developing appropriate poverty alleviation programmes for Kigali city. 


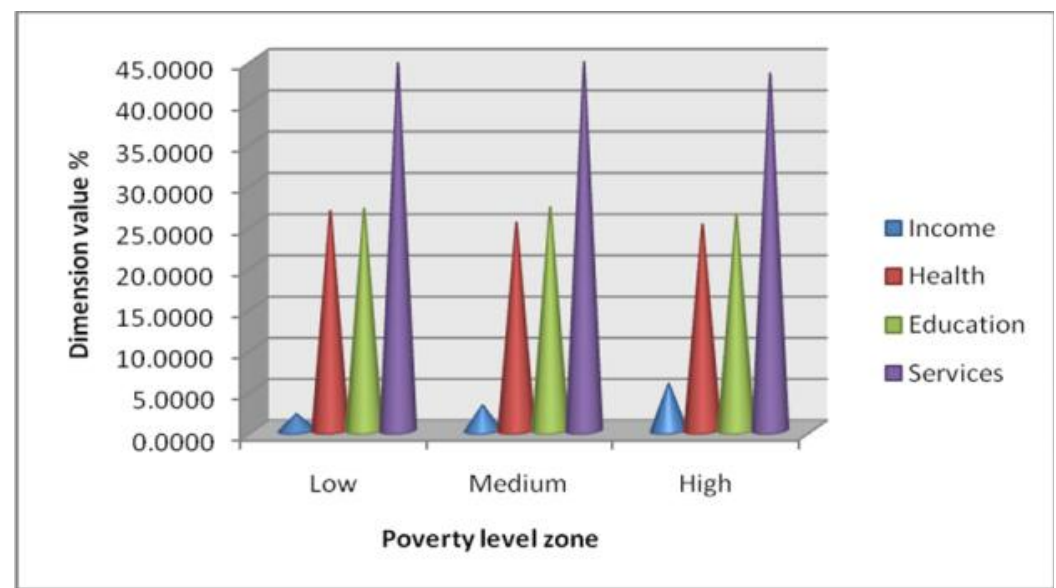

Figure 7: Dimensions and the influence they exact on the poverty level in Kigali city

\section{Conclusion}

This study examined the level of poverty as captured by the household living conditions survey data in Kigali city. For the data analysis, 4 dimensions of expenditure/income, health, education and access to services were captured through 10 indicators. The monetary indicators computed and mapped include the poverty headcount and poverty gap indices. Nonmonetary indicators are percentage of people using medical health care, people without any medical insurance, people using safe water, households without a water closet or chemical toilet, population in sub-standard housing, enrolment rate at primary and secondary level of education, persons age $15+$ with no schooling. However, the combination of the monetary and non-monetary indicators gave the composite index of household living standard which is interpreted as the poverty levels.

Based on the composite index, 3 zones of poverty were identified, namely: low, medium and high poverty. Results were further disaggregated to decipher the contributions made by each indicator to the overall poverty levels, that is, the influence exerted by every dimension. In the city as a whole (in all 3 poverty zones), the expenditure/income dimension contributed only $3.66 \%$, health $25.58 \%$, education $26.58 \%$ and services contributed $44.19 \%$ to the overall poverty level. The implication of these findings is that access to services by househlds exerts the greatest influence on overall poverty pattern in Kigali city. If a positive change to the situation is to be achieved, appropriate poverty alleviation strategy for the city must focus more on service provision such as access to clean water, sanitation among others. 
In summary, results show that the central part of the city is better off in terms of the household living conditions whatever the indices chosen, whereas other parts vary from medium to high poverty conditions. Thus a very vivid and more informative pattern of poverty levels in the city was derived. A simple but efficient procedure based on GIS spatial analysis was developed and utilized to derive the composite household living condition index for the city. Further research is required to fine-tune this procedure for use in other studies as this study's presentation of poverty and welfare maps is unique in Rwanda.

\section{References}

1. Antonic O., Krizan J., Marki A. \& Bukovec D. 2001. Spatio-temporal interpolation of climatic variables over large region of complex terrain using neural networks. Ecological Modelling 138, pp. 255-63

2. Baharoglu D. \& Kessides C. 2002. A sourcebook for Poverty Reduction Strategies: Chap 16: Urban Poverty. Available at http://siteresources. worldbank.org/INTPRS1/Resources/383606205334112622/4418 chap 16.pdf

3. Baker J. L. \& Grosh M. E. 1994. Measuring the Effects of Geographic Targeting on Poverty Reduction. Washington DC: World Bank Living Standards and Measurement Survey working paper No. 99.

4. Bedi T., Coudouel A. \& Simler K. (eds) 2007. More Than a Pretty Picture: Using Poverty Maps to Design Better Policies and Interventions. Washington DC: World Bank.

5. Davis B. 2003. Choosing a Method for poverty mapping. Rome: FAO.

6. ESRI. 2010. ArcGis 9.2 Desktop Help. Available at http://webhelp.esri.com/arcgisdesktop/9.2/index.cfm?TopicName=weig hted_overlay

7. Fleming M. D., Chapin F. S., Cramer W., Hufford G. L., \& Serreze M. C. 2000. Geographic patterns and dynamics of Alaskan climate interpolated from a sparse station record. Global Change Biology, 6(1), pp.49-58.

8. Foster J., Greer J. \& Thorbecke E. 1984. A class of decomposable poverty measures. Econometrica, 52, pp.761-765.

9. Hartkamp A. D., De Beurs K., Stein A. \& White J. W. 1999. Interpolation Techniques forClimate Variables. Mexico, International Maize and Wheat Improvement Centre Mexico, NRG-GIS Series 9901.

10. Hudson G. \& Wackernagel H. 1994. Mapping temperature using kriging with external drift: Theory and example from Scotland, International Journal of Climatology 14, pp. 77-91. 
11. Jeffrey S. J., Carter J. O., Moodie K. B., \& Beswick A. R. 2001. Using spatial interpolation to construct a comprehensive archive of Australian climate data. Environmental Modelling and Software 16(4), pp. 309330.

12. Kanbur S. M. R. 1987. Transfer, targeting and poverty. Economic Policy 4, pp.111-198.

13. Kigali City Council 2007. Kigali Conceptual Master plan. Kigali: Republic of Rwanda.

14. MINECOFIN 2000. Rwanda Vision 2020. Kigali: Republic of Rwanda.

15. MINECOFIN 2007. Economic Developemnt and Poverty Reduction Strategy 2008-2012. Kigali: Republic of Rwanda.

16. MINECOFIN 2009. Annual Report on the Implementation of the Economic Development and Poverty Reduction Strategy (EDPRS)2008. Kigali: Republic of Rwanda.

17. Osberg L. \& Kuan X. 2008. How should we measure poverty in a changing world? Methodological issues and Chinese case study. Review of Development Economics 12(2), pp. 419-441.

18. Price D. T., McKenney D. W., Nadler I. A., Hutchinson M. F., \& Kesteven J. L. 2000. A comparison of two statistical methods for spatial interpolation of Canadian monthly mean climate data. Agriculture for Meteorology 101, pp. 81-94.

19. Rigol J. P., Jarvis C. H. \& Stuart N. 2001. Artificial neural networks as a tool for spatial interpolation. International Journal of Geographical Information Science 15, pp. 323-343.

20. Thiessen A. H. 1911. Precipitation averages for large areas. Monthly Weather Review 39: 1082-1084 of Australian climate data. Environmental Modelling and Software 16(4), pp. 309-330

21. UNDP 2000. Poverty Report: Overcoming Human Poverty. New York. United Nations Development Programme.

22. UNDP 2005. Human Development Report 2005. New York: Oxford University Press.

23. UNDP. 2006. Millenium Development Goals. Available at $\mathrm{http} / / / \mathrm{www}$.undp.org/mdg/basics.shtml

24. World Bank 2009. Poverty manual. Available at http://siteresources.worldbank.org/PGLP/Resources/PovertyManual.pdf 